\title{
Semantic Guidelines and Conceptual Basis of a Social Education Teacher Professional Mobility in the Pedagogical Science
}

\author{
Zhanat Nurzhanbayeva, Bakhtzhan Aidarov, Almagul Baltabekova, Gavkharbek \\ Makhmudov, Yusubaly Kamalov and Nayila Seisen
}

Korkyt Ata Kyzylorda State University, Kazakhstan

\begin{abstract}
The article is dedicated to enhancing urgent scientific problems, which is considered the formation of professional mobility of future teachers of professional training as one of the main components of the modernization of their professional training system.

The purpose of the article is to show the results of the scientific search for semantic guidelines and the structure of professional mobility of future teachers of professional training in the conceptual basis of pedagogical science.

The main goal of this research paper was a kind of report on the author's vision of the essence of professional mobility of future teachers in the structure of their professional readiness and scientific results, and acquaint readers with the opinion of scientists on the semantic guidelines and structure of professional mobility of future teachers based on a review of various information sources on selected topics;

The leading idea of the publication of the article "Semantic guidelines and structure of professional mobility of a teacher in the conceptual basis of pedagogical science" is to share the experience of identifying the semantic guidelines and structure of professional mobility of future teachers of professional training.

Then the concept of "the formation of professional mobility of future teachers of professional training" will be presented as a motivated, focused, and informed process of professional training, reflecting the dynamics of the development of its components and providing predicted changes, professional self-realization, and a quantitative increase in the indicators of the transition of subjects from a low level of mobility to a higher one by creating a system of pedagogical tools.
\end{abstract}

Keywords: Professional mobility, the structure of professional mobility, a teacher of professional training.

\section{INTRODUCTION}

The development of the formation of professional mobility of future teachers of professional training at the modern stage is one of the central in the Republic of Kazakhstan's professional education. A teacher as a specialist is not born formed. They need to be formed. Especially it regards the professional mobility of the teacher. His prompt response to constantly changing living conditions and the ability to flexibly reorganize the content of his activities in relation to the labor market requirements will depend on how high the level of professional mobility will be formed for each graduate of a pedagogical university [1].

In other words, modern professional education is a process of formation and development of attitudes (value-semantic relations), representations, knowledge, abilities, skills necessary for engaging in a certain profession. Professional education is implemented in the process of professional training, education, and development, such as S.A. Zholdasbekova, E.F. Zeyer, V.V. Kuznetsov, A.K. Markova, A.Ya. Nain, A.A. Rean [2].

*Address correspondence to this author at the Kazakh State National University of Al-Farabi, Almaty, Kazakhstan; Tel: +77073851878 ;

E-mail: zhanat_2006@mail.ru
The purpose of this research is to analyses training a teacher of professional training at the university and to form a specialist in a new formation capable of: implementing a holistic pedagogical process in institutions of primary, secondary, higher, and additional professional education and in production. Participation in diverse areas of professional activity. The operational solution of scientific, psychological, pedagogical, and production-technological problems.

Based on the goal and qualification characteristics of the graduate of the specialty "Professional training", we, in the combination of factors determining the success of the training of a teacher of professional training, give the most important role to the formation of his professional mobility. Since the specifics of the teacher's activity are such that professional mobility becomes its hallmark, without the formation of which our graduate will not take place either as a person or as a professional.

An analysis of numerous publications, dissertation research, and personal pedagogical experience shows: the problems and prospects of professional mobility are investigated and researched by representatives of different sciences. And each science contributes to the mobile response to ongoing changes in various fields and processes of human life. 
Various aspects of the problem of professional mobility attract the attention of scientists from far abroad [3-5].

The problem of professional mobility in various areas completed in the dissertation research of $\mathrm{Yu} \mathrm{Yu}$ Dvoretskaya investigated the psychological components of the professional mobility of a person [6]. L.A. Amirova considers the professional mobility of a teacher in the system of additional education [7].

B.M. Igoshev studied the system-integrative organization of training professionally-mobile teachers [9]. Yu I. Kalinovskiy studies the problems of developing social and professional mobility in the context of the socio-cultural educational policy of the region [10]. S.E. Kaplina developed the conceptual and technological foundations of the formation of the professional mobility of future engineers [11].

E.F. Zeyer, arguing about the ambiguity of the concept of "professional mobility", connects it with social and personal competencies, sees in it the employee's willingness and ability to change their production tasks, and learn new specialties [12].

If we compare professional mobility with the position of sociology and pedagogy, then we can say that this is a process. And in psychology, the category of "professional mobility" acts mainly as quality of personality. Recognizing this category as a personality quality, the pedagogue V.A. Mishchenko notes that "this quality to a certain extent is inherent in various people to varying degrees initially, and, at the same time, it can be formed in the process of socialization" [13].

There are other opinions about the nature of professional mobility. For example, A.N. Semuchenko believes that the basis of professional mobility is, above all, a high level of generalized professional knowledge [14].

L. Sushentseva, at the basis of the personality's professional mobility, sees the dynamism of its motivational, intellectual, and volitional processes, which creates an individual field of readiness for professional mobility [15].

Yu.I. Kalinovskiy highlighted such personality traits and qualities as: openness to the world, trust in people and in himself, flexibility, efficiency, localization of control, tolerance; skills: reflection, self-regulation, selfdetermination, goal-setting; ability: to see and understand the essence of changes in society; see the variability and alternative development of the situation; to think constructively, productively (creative thinking); to design the necessary changes in microsocium, group; to solve problems; adapt to changes (redesign) [16].

Based on the analysis and generalization of the source materials, we illustrate the semantic content of the concept of "professional mobility" in the interpretation of various scientists (Table 1).

Analyzing the variety of interpretations of the phenomenon of "professional mobility" in the works of individual authors and Table 1, we pay attention to its trilateral nature, which was pointed out by researcher Goryunova L.V. [8].

On the first hand, professional mobility acts as a personality trait that provides an internal mechanism for human development by forming a high level of general professional knowledge and possession of a system of generalized professional techniques and key competencies.

On the second - as a person's activity, determined by changing conditions, the result of which is the ability to flexibly adapt and creatively fulfill oneself in the profession in life according to the labor market's requirements.

On the third - as a process of personality formation and transformation by a person of himself and his surrounding life and professional environment.

Here we can say that a person can be mobile, flexibly rebuild and creatively fulfill himself within the framework of his acquired profession in life. But only if he has certain personal and professional qualities. A set of competencies. The degree and level of its mobility can manifest itself only if it is implemented in activities in the process of professional and personal formation. It is constantly changing living conditions according to the requirements of the labor market. And, of course, with the active use of pedagogical tools and technologies, effective use of the potential of the educational environment. Just then, many of the qualities and properties that form the basis of professional mobility of a future specialist will receive a powerful incentive for his development as an individual and a professional.

Talking about the semantic guidelines of professional mobility, we can say that mobility is 
Table 1: The Semantic Content of the Categorical Concept of "Professional Mobility" in the Various Information Source

\begin{tabular}{|c|c|c|}
\hline Concept & Definition & Author \\
\hline Mobility & $\begin{array}{l}\text { 1. Mobile, capable of rapid movement; } 2 \text {. able to act quickly, } \\
\text { make decisions. }\end{array}$ & Ozhegov S.I., Shvedova N.Yu. \\
\hline Mobility & $\begin{array}{l}\text { The trend towards activities aimed at meeting the growing } \\
\text { material and spiritual needs, the desire to achieve harmony } \\
\text { with the whole world and himself as part of this world }\end{array}$ & Encyclopedia. Sociology / A.A. Gritsanov \\
\hline Mobility & $\begin{array}{l}\text { The opportunity and ability to successfully switch to another } \\
\text { activity or change the type of work; high level of generalized } \\
\text { professional knowledge, readiness for the prompt selection } \\
\text { and implementation of optimal methods for performing } \\
\text { various tasks in the field of their profession. }\end{array}$ & Biktuganov Yu.A., Igoshev B.M. \\
\hline $\begin{array}{l}\text { Professional } \\
\text { mobility }\end{array}$ & $\begin{array}{c}\text { Constant internal (personal-psychological) and external } \\
\text { (practical-activity) readiness for changes, quick response to } \\
\text { them, social and professional mobility }\end{array}$ & $\begin{array}{l}\text { Site for psychologists and students /psinovo.rus } \\
\quad \ldots \text { po...i....professionalnaya_mobilnost.html }\end{array}$ \\
\hline $\begin{array}{l}\text { Professional } \\
\text { mobility }\end{array}$ & $\begin{array}{l}\text { The integral dynamic quality of the personality, which } \\
\text { determines the success of its adaptation to the changing } \\
\text { conditions of professional activity, readiness to master } \\
\text { innovations in education and to self-improvement, self- } \\
\text { development, self-realization in pedagogical activity and the } \\
\text { professional community. }\end{array}$ & Igoshev B.M. \\
\hline $\begin{array}{l}\text { Professional } \\
\text { mobility }\end{array}$ & $\begin{array}{l}\text { Integral quality of the subject of innovative activity, where the } \\
\text { substantive components are: the choice of a profession, } \\
\text { improvement in it, determining the conditions for changing } \\
\text { the place of work or profession. }\end{array}$ & Zeyer E.F., Morozova S.A., Symanyuk E.E. \\
\hline $\begin{array}{l}\text { Professional } \\
\text { mobility }\end{array}$ & $\begin{array}{l}\text { The mechanism of personality adaptation associated with the } \\
\text { process of subjective formation }\end{array}$ & Dvoretskaya Yu.Yu. \\
\hline $\begin{array}{l}\text { Professional } \\
\text { mobility }\end{array}$ & $\begin{array}{l}\text { The orientation of the personality, presented in its structure } \\
\text { as a value-semantic construct in the unity of personal } \\
\text { qualities and formations. }\end{array}$ & Amirova L.A. \\
\hline $\begin{array}{l}\text { Professional } \\
\text { mobility }\end{array}$ & $\begin{array}{c}\text { An integrative characteristic of the readiness and ability of a } \\
\text { person to qualitatively and quickly mastering key and } \\
\text { professional competencies. }\end{array}$ & Solonenko, V.A. \\
\hline $\begin{array}{l}\text { Professional } \\
\text { mobility }\end{array}$ & $\begin{array}{c}\text { Personality characteristics necessary for the integration of } \\
\text { professional development. }\end{array}$ & Markova, A.K. \\
\hline $\begin{array}{l}\text { Professional } \\
\text { mobility }\end{array}$ & $\begin{array}{l}\text { Integrative characteristic of the engineer's readiness for } \\
\text { successful adaptation in the production conditions, including } \\
\text { a combination of the basic components of professional } \\
\text { culture and professional competence }\end{array}$ & Kaplina S.E. \\
\hline $\begin{array}{l}\text { Professional } \\
\text { mobility }\end{array}$ & $\begin{array}{l}\text { A long process of quantitative and qualitative changes in the } \\
\text { personality and activity characteristics of the subject of } \\
\text { professional activity associated with self-positioning in the } \\
\text { labor market under the influence of various objective and } \\
\text { subjective factors. }\end{array}$ & Lvov A.Yu. \\
\hline $\begin{array}{l}\text { Professional } \\
\text { mobility }\end{array}$ & $\begin{array}{l}\text { A personality trait contributes to a quick response to a } \\
\text { situation of difficulty and actualizes all the potential } \\
\text { possibilities of a student's subjective activity when choosing } \\
\text { options and methods for solving professional-pedagogical } \\
\text { problems and predicting professional self-realization. }\end{array}$ & Nikitina E.A. \\
\hline $\begin{array}{l}\text { Professional } \\
\text { mobility }\end{array}$ & Professional competency criterion & Shpakina, I.G. \\
\hline $\begin{array}{l}\text { Professional } \\
\text { mobility }\end{array}$ & $\begin{array}{c}\text { The quality of a person, reflecting his abilities and willingness } \\
\text { to change his profession and due to personal abilities, } \\
\text { external living conditions, and his socialization, including } \\
\text { directed professional and psychological training received in } \\
\text { various educational structures }\end{array}$ & Mishchenko V.A \\
\hline
\end{tabular}


(Table 1). Continued.

\begin{tabular}{|c|c|c|}
\hline Concept & Definition & Author \\
\hline $\begin{array}{l}\text { Professional } \\
\text { mobility }\end{array}$ & $\begin{array}{l}\text { The integral quality of personality, expressed in the student's } \\
\text { internal orientation to change the type and / or place of } \\
\text { professional activity, manifested in self-analysis and self- } \\
\text { esteem, in the desire and ability to develop professionally, to } \\
\text { achieve success, }\end{array}$ & Kerdyasheva O.V. \\
\hline $\begin{array}{l}\text { Professional } \\
\text { mobility }\end{array}$ & $\begin{array}{c}\text { The type of activity of the subject, which is to master new } \\
\text { achievements within the framework of a profession acquired } \\
\text { or master a new profession. }\end{array}$ & Malygina O. A. \\
\hline $\begin{array}{c}\text { Professional } \\
\text { mobility of a teacher }\end{array}$ & $\begin{array}{l}\text { The ability and readiness of a personality to quickly and } \\
\text { successfully master new equipment and technology, acquire } \\
\text { the missing knowledge and skills that ensure the } \\
\text { effectiveness of new professional activities }\end{array}$ & Psychology. Dictionary \\
\hline $\begin{array}{l}\text { Formation of } \\
\text { professional mobility } \\
\text { of future teachers }\end{array}$ & $\begin{array}{l}\text { The process of professional training, which is based on the } \\
\text { interaction of all subjects of the educational process at the } \\
\text { university }\end{array}$ & Nikitina E.A. \\
\hline $\begin{array}{l}\text { Formation of } \\
\text { professional- } \\
\text { pedagogical } \\
\text { mobility }\end{array}$ & $\begin{array}{l}\text { Systematic movement, including a number of interconnected } \\
\text { stages: diagnostic, extensive, intensive, innovative, practice- } \\
\text { oriented, implemented through appropriately selected } \\
\text { methods and means }\end{array}$ & Kipina O.A. \\
\hline
\end{tabular}

directly related to the individual's adaptation to the needs of the market, the satisfaction of the needs for professional self-education, self-improvement, selfchange, self-development.

Professional mobility is characterized not only by a person's ability to change his profession, place, occupation, and so on, but also by the ability to make independent and non-standard decisions aimed at improving his professional skills. It serves as a guarantee of demand in the labor market, material security in conditions of fierce competition.

In the essential characteristic of professional mobility, scientists distinguish between its objective, subjective and characterological aspects. The objective side includes the scientific, technical, and socioeconomic prerequisites entailing forced changes in the profession and status position, as well as the process of these changes. The composition of the subjective side refers to the process of changing the interests of the employee and the motive for deciding on changing professional status, changing the place of work or occupation. Professional mobility acts as a more or less stable personality trait from a characterological position, as a preparedness or predisposition to master related professions and change the scope of work.

Based on the preceding, we can introduce the structure of professional mobility (Figure 1)

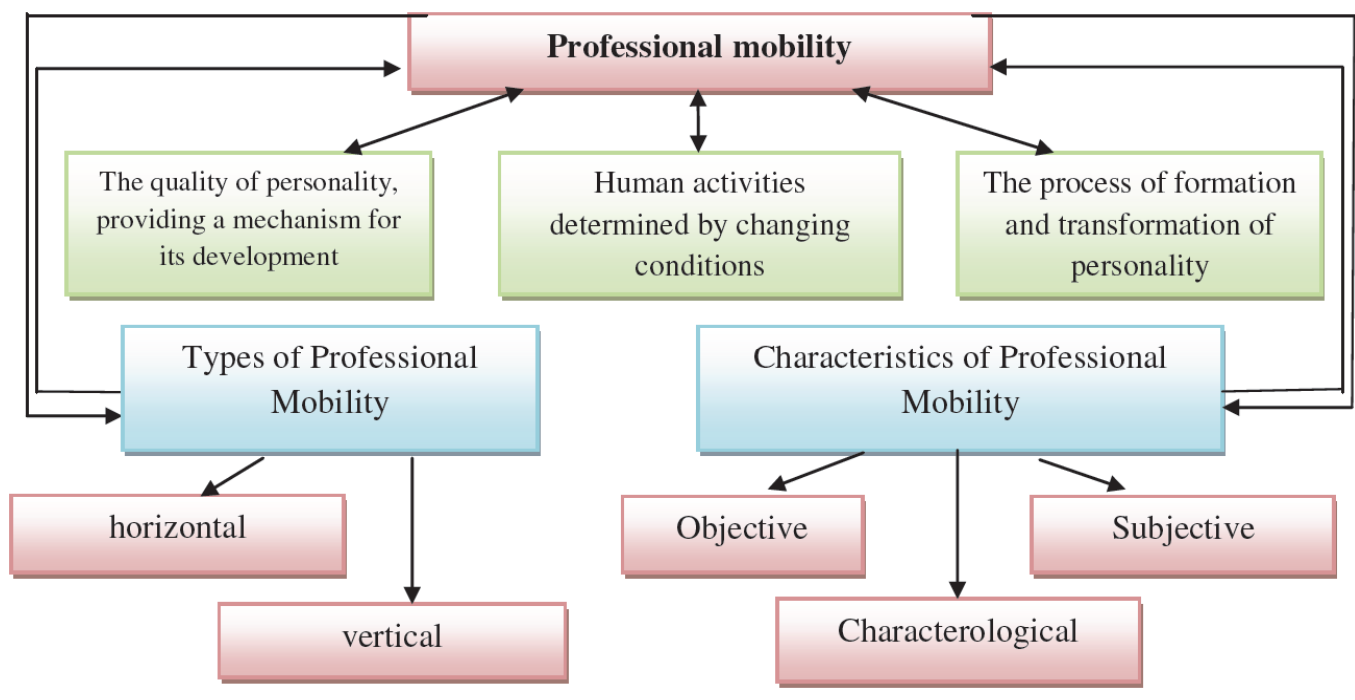

Figure 1: Professional mobility structure. 
As you can see, the structure of professional mobility is represented by the unity of its main elements:

- personal qualities that provide an internal mechanism for human development through the formation of the key, general professional competencies;

- $\quad$ human activity, determined by events changing the environment, the result of which is the selfrealization of a person in the profession in life;

- $\quad$ the process of human transformation of himself and his surrounding professional and living environment;

- types of professional mobility: vertical and horizontal;

characteristics of professional mobility: objective, subjective, and characterological.

\section{METHODS}

During the research, the following methods were used: an interdisciplinary analysis and data synthesis of the philosophical, sociological, natural scientific, psychological and educational literature; analysis of foreign and domestic psychological and pedagogical experience for the formation of a mobile person in the educational systems; conversation, written survey, interviewing teachers and heads of educational institutions, the method of expert evaluations and selfevaluations; a method of self-managed adults, summarizing these results and ascertaining the formative experiment.

The study's empirical base was a selective sociological survey representative for Kazakhstan, conducted in the South-Kazakhstan region. The study's representativeness and reduction of sampling error were conditioned by a sufficiently high homogeneity, the given orderliness of the target audience.

The study was conducted by a method of survey, which was filled out by teachers in a written form. The survey sheet was the same in all institutions of the South-Kazakhstan region, on the faculties which train the students in specialty "Pedagogy and psychology". There were 18 educational institutions in Shymkent and 20 regional institutions in Kazakhstan.

In total, 188 people participated in the survey.
The study was being conducted in 2019. Research has been conducted among teachers to indicate the level of mobility, also how do they apply in practice their knowledge received during learning theory. The results attained from this research and observation from the experiment let us interpret in the following way.

\section{RESULTS AND DISCUSSION}

The results of empirical research on professional and personal mobility are presented in Table $\mathbf{2}$.

Table 2:

\begin{tabular}{|c|c|c|c|}
\hline levels of mobility & teachers & educators & psychologists \\
\hline \hline cognitive & $25 \%$ & $65 \%$ & $1-\%$ \\
\hline motivational & $73 \%$ & $11 \%$ & $18 \%$ \\
\hline activity-based & $45 \%$ & $15 \%$ & $40 \%$ \\
\hline
\end{tabular}

First of all, the degree of management and professional and personal mobility of teachers underwent assessment, as the implementation of the standard depends on them in many respects. Motivational (personal) level of mobility as a vocational teaching viewpoint is formed among the minority of managers $(17 \%), 83 \%$ do not believe in the positive impact of the introduction of education standard on the development and education of children, and that it contributes to the improvement of the educational process. Apparently, therefore, there have been observed superficial motivations for professionalpedagogical self-education among respondents. The activity-based level of mobility for the implementation of the standard of education as vocational and educational performance is also formed only among half of the teachers $(50 \%)$ at institutions.

The rest of the educators are having trouble developing a basic educational program, designing an individual trajectory of a child, parent education, and inclusive education. First of all, the degree of management and professional and personal mobility of heads of institutions of pre-school education underwent assessment, as the implementation of the standard depends on them in many respects.

Motivational (personal) level of mobility as a vocational teaching viewpoint is formed among the minority of managers $(25 \%), 65 \%$ make a positive impact of the introduction of education standard on the 
development and education, and that it contributes to the improvement of the educational process. Therefore, there have been observed superficial motivations for professional-pedagogical self-education among respondents.

The activity-based level of mobility for the implementation of the standard of pre-school education as vocational and educational performance is also formed only among half of the educators (50\%) at institutions.

The cognitive level of mobility as a theoretical psychological, and pedagogical part of professional and personal mobility is typical for teachers of educational institutions.

The activity-based level of mobility for the implementation of the standard of education, as professionally and pedagogical effectiveness has also been formed a little more than among half of the teachers at institutions.

In our opinion, the weak formedness of activitybased mobility in the field of implementation of the standard of education significantly reduces the cognitive component of educators' professional mobility. Assessing own mobility in the implementation of educational activities in the conditions of the introduction of the standard of education, psychologists note the high level of mobility on the cognitive and activity levels, at the same time motivational (personal) level of mobility is marked only among half of the psychologists (50\%).

\section{CONCLUSION}

Summing up the results of the study and summarizing professional and personal mobility of teaching staff to ensure the implementation of the educational standards of education, the following conclusions can be drawn: the cognitive level of mobility as a theoretical psycho-pedagogical part of professional readiness is formed more than among half of the respondents $(65 \%)$. They are confident in their understanding of the theoretical foundations of the standard and demonstrate awareness of the ways and means to implement it, indicating thereby the lack of any difficulties in the cognitive term.

The activity-based level of respondents' mobility in the implementation of the standard of pre-school education as a professional-pedagogical performance is noted only among half of them $(50 \%)$. The rest of the respondents experience difficulties in the development of the basic educational program, in the design of the individual trajectory of a child, parent enlightenment, and the implementation of inclusive education.

During the search and analytical stage of the study, information and empirical data were collected and analyzed, and criteria for promoting students from one level of professional mobility to another were predicted.

Guided by the described semantic guidelines in the conceptual field of professional mobility, we outline our understanding of the essence of the concept of "professional mobility of a future teacher of professional training". In a generalized form, the concept of "professional mobility of a future teacher of professional training is an "integral quality of a person that provides quick and successful mastery of general professional knowledge, new equipment and technologies, a system of generalized professional techniques of solving pedagogical problems, the opportunity and ability to quickly change professional status in the changing labor market conditions".

Further understanding of the topic under study leads to the search and concretization of the criteria and indicators of the formation of professional mobility of the future teacher of professional training and the refinement of diagnostic methods for assessing its effectiveness.

\section{ACKNOWLEDGMENT}

None.

\section{REFERENCES}

[1] Ustemirov K, Shametov N, Vasiliyev IB. Meet: Textbook "Professional Pedagogy". "Mekteptegi tehnologiia. Technology at school" 2004; 10: 33-34.

[2] Morozova SA, Symanyuk EE. Professional mobility as a factor in the implementation of innovative activities of a teacher. Education and Science 2012; 4(93): 50-60. https://doi.org/10.17853/1994-5639-2012-4-50-60

[3] Eribon R, Goldthorpe JH. The constant flux. A study of class mobility in industrial societies. - Oxford: Clarendon Press. 1992; p. 429.

[4] Dunkan ON. Mobility in Britain reconsidered. Ed. by. I.M. Ridge Oxford, Clarendenpriss 1973; p.120.

[5] Goldthorpe JH. Introduction: Social Mobility and Social Interests. Social Mobility and Class Structure in Modern Britain. 2nd ed. - Oxford: Clarendon Press 1987; pp. 1-37.

[6] Falch T. Teacher mobility responses to wage changes: Evidence from a quasi-natural experiment. American Economic Review 2011; 101(3): 460-465. https://doi.org/10.1257/aer.101.3.460

[7] Amirova LA. Development of professional mobility of a teacher in the system of additional education: Author's 
abstract...Doctor of Pedagogical Sciences 2009; 13.00.08. Ufa..- p. 43.

https://doi.org/10.1080/13664530902858493

[8] Neprokina IV, Stepanova IA. Professional mobility of teachers as a prerequisite for modernization of contemporary pre-school education. Young Scientist 2015; 23: 993-995.

[9] Igoshev BM. System-integrative organization of training professionally-mobile teachers: Abstract ... diss. Doctor of Pedagogical Sciences 13.00.08.-M.: 2008; p. 43.

[10] Rickman BD, Parker CD. Alternative Wages and Teacher Mobility: A Human Capital Approach Economics of Education Review 1990; 9(1): 73-79. https://doi.org/10.1016/0272-7757(90)90033-2

[11] Kaplina SE. Conceptual and technological foundations for the formation of professional mobility of future engineers in the process of studying humanitarian disciplines: Author's abstract ... Doctor of Pedagogical Sciences: 13.00.08 Cheboksary 2008; p. 44.
[12] Zeyer EF. The ambiguity of the phenomenon of "mobility" in professional education. Social and professional mobility in the XXI century. Collection of materials and reports of the International Conference (Yekaterinburg, May 29-30, 2014), Yekaterinburg 2014; pp. 30-36.

[13] Mishchenko VA. On the interpretation of the concept of "professional mobility" in modern scientific literature. Siberian Pedagogical Journal. HAC 2008; 15: 75-81.

[14] Semuchenko AN. Andragogical features of the development of professional mobility of undergraduates. Electronic scientific publication (scientific and pedagogical journal), St. Petersburg: GPU. August 2014.

[15] Sushentseva L. The problem of professional mobility in the context of an interdisciplinary approach. Theory and methodology of professional education 2011; 1 : 7.

[16] Kerdyasheva OV. Pedagogical conditions for the formation of readiness for professional mobility of students in the educational process of a university: thesis - Voronezh 2010; p. 204.

\section{DOI: https://doi.org/10.6000/2292-2598.2020.08.03.33}

(C) 2020 Nurzhanbayeva et al.; Licensee Lifescience Global.

This is an open access article licensed under the terms of the Creative Commons Attribution Non-Commercial License (http://creativecommons.org/licenses/by-nc/3.0/) which permits unrestricted, non-commercial use, distribution and reproduction in any medium, provided the work is properly cited. 